\title{
Summary of Optical-Backscatter and Suspended-Sediment Data, Tomales Bay Watershed, California, Water Years 2004, 2005, and 2006
}

By Jennifer A. Curtis

Scientific Investigations Report 2007-5224 


\section{U.S. Department of the Interior \\ DIRK A. KEMPTHORNE, Secretary \\ U.S. Geological Survey \\ Mark D. Myers, Director}

U.S. Geological Survey, Reston, Virginia: 2007

For product and ordering information:

World Wide Web: http://www.usgs.gov/pubprod

Telephone: 1-888-ASK-USGS

For more information on the USGS--the Federal source for science about the Earth, its natural and living resources, natural hazards, and the environment:

World Wide Web: http://www.usgs.gov

Telephone: 1-888-ASK-USGS

Any use of trade, product, or firm names is for descriptive purposes only and does not imply endorsement by the U.S. Government.

Although this report is in the public domain, permission must be secured from the individual copyright owners to reproduce any copyrighted materials contained within this report.

Suggested citation:

Curtis, J.A., 2008, Summary of Optical-Backscatter and Suspended-Sediment Data, Tomales Bay Watershed, California, Water Years 2004, 2005, and 2006: U.S. Geological Survey Scientific Investigations Report 2007-5224, 16 p. 


\section{Contents}

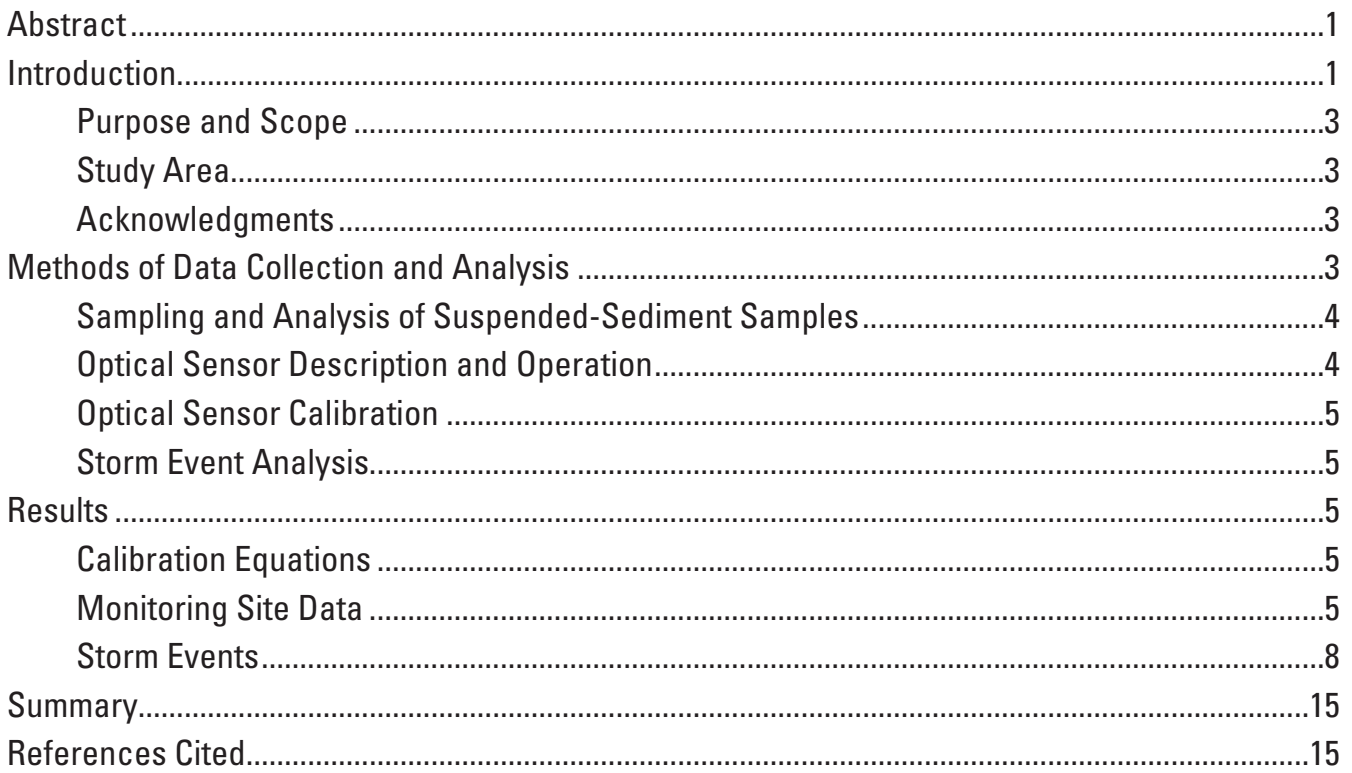

\section{Figures}

Figure 1. Map showing location of Tomales Bay, Lagunitas Creek watershed, Walker Creek watershed, and sediment and streamflow gaging stations $\ldots \ldots \ldots \ldots \ldots \ldots \ldots \ldots \ldots \ldots \ldots \ldots$

Figure 2. Graphs showing optical-backscatter sensor calibration, $(A)$ first sensor deployed November 21, 2003, through January 21, 2005, and $(B)$ second sensor deployed January 21, 2005, through June 1, 2006, at Lagunitas Creek at Samuel P. Taylor State Park, California

Figure 3. Graphs showing optical-backscatter sensor calibration, $(A)$ first sensor deployed November 21, 2003, through January 21, 2005, and (B) second sensor deployed January 21, 2005, through June 1, 2006, at Walker Creek near Marshall, California

Figure 4. Graphs showing instantaneous streamflow, measured suspended-sediment concentrations, and estimated suspended-sediment concentrations, Lagunitas Creek at Samuel P. Taylor State Park, California, (A) water year 2004, (B) water year 2005, and (C) water year 2006

Figure 5. Graphs showing instantaneous streamflow and uncalibrated/edited opticalbackscatter data, Lagunitas Creek near Point Reyes Station, California,

$(A)$ water year 2004, (B) water year 2005, and (C) water year 2006

Figure 6. Graphs showing instantaneous streamflow, measured suspended-sediment concentrations, and estimated suspended-sediment concentrations, Walker Creek near Marshall, California, $(A)$ water year 2004, $(B)$ water year 2005, and (C) water year 2006 
Figure 7. Graphs showing ratio of suspended-sediment concentration to opticalbackscatter sensor-output voltage as a function of suspended particles finer than 0.063 millimeter, $(A)$ first sensor deployed November 21, 2003, through January 21, 2005, and (B) second sensor deployed January 21, 2005, through June 1, 2006, at Lagunitas Creek at Samuel P. Taylor State Park, California

Figure 8. Graphs showing ratio of suspended-sediment concentration to opticalbackscatter sensor-output voltage as a function of suspended particles finer than 0.063 millimeter, $(A)$ first sensor deployed November 21, 2003, through January 21, 2005, and $(B)$ second sensor deployed January 21, 2005, through

June 1, 2006, at Walker Creek near Marshall, California 13

\section{Tables}

Table 1. Annual seasonal suspended-sediment yield at Tomales Bay watershed stream gaging stations during water years 2004, 2005, and 2006

Table 2. Percentages of valid optical backscatter data collected at Tomales Bay watershed stream gaging stations during water years 2004, 2005, and 2006 8

Table 3. Storm event data for Tomales Bay watershed gaging stations during water years 2004, 2005, and 2006

Appendixes: Data collected at Lagunitas Creek at Samuel P. Taylor State Park, Lagunitas Creek near Point Reyes Station, and Walker Creek near Marshall, California. Appendix A. In Excel format Appendix B. In Excel format 


\section{Conversion Factors}

Inch/Pound to SI

\begin{tabular}{|c|c|c|}
\hline Multiply & By & To obtain \\
\hline \multicolumn{3}{|c|}{ Length } \\
\hline foot $(\mathrm{ft})$ & 0.3048 & meter $(\mathrm{m})$ \\
\hline \multicolumn{3}{|c|}{ Area } \\
\hline square mile $\left(\mathrm{mi}^{2}\right)$ & 2.590 & square kilometer $\left(\mathrm{km}^{2}\right)$ \\
\hline \multicolumn{3}{|c|}{ Volume } \\
\hline cubic foot $\left(\mathrm{ft}^{3}\right)$ & 0.02832 & cubic meter $\left(\mathrm{m}^{3}\right)$ \\
\hline \multicolumn{3}{|c|}{ Flow rate } \\
\hline foot per second $(\mathrm{ft} / \mathrm{s})$ & 0.3048 & meter per second $(\mathrm{m} / \mathrm{s})$ \\
\hline cubic foot per second $\left(\mathrm{ft}^{3} / \mathrm{s}\right)$ & 0.02832 & cubic meter per second $\left(\mathrm{m}^{3} / \mathrm{s}\right)$ \\
\hline \multicolumn{3}{|l|}{ SI to Inch/Pound } \\
\hline Multiply & By & To obtain \\
\hline millimeter $(\mathrm{mm})$ & 0.03937 & inch \\
\hline
\end{tabular}

Dual units are used in this report. English units are used throughout with the exception of suspended-sediment concentration, grain size, and optical backscatter data, which are presented in milligrams per liter (mg/L), millimeters $(\mathrm{mm})$, and millivolts $(\mathrm{mV})$.

\section{Abbreviations}

$\begin{array}{ll}\text { ADAPS } & \text { automated data processing system } \\ \text { BU } & \text { backscatter units } \\ \text { FBU } & \text { formazin backscatter units } \\ \text { NTU } & \text { nephelometric turbidity units } \\ \text { OBS } & \text { optical backscatterance sensor } \\ \text { PRS } & \text { Point Reyes Station } \\ \text { SFRWQCB } & \text { San Francisco Bay Regional Water-Quality Control Board } \\ \text { SPT } & \text { Samuel P. Taylor (State Park) } \\ \text { SSC } & \text { suspended-sediment concentration } \\ \text { TMDL } & \text { total maximum daily loads }\end{array}$


This page intentionally left blank. 


\title{
Summary of Optical-Backscatter and Suspended- Sediment Data, Tomales Bay Watershed, California, Water Years 2004, 2005, and 2006
}

\author{
By Jennifer A. Curtis
}

\section{Abstract}

The U.S. Geological Survey, in cooperation with Point Reyes National Seashore, is studying suspended-sediment transport dynamics in the two primary tributaries to Tomales Bay, Lagunitas Creek and Walker Creek. Suspended-sediment samples and continuous optical backscatter (turbidity) data were collected at three locations during water years 2004-06 (October 1, 2003-September 30, 2006): at two sites in the Lagunitas Creek watershed and at one site in the Walker Creek watershed. Sediment samples were analyzed for suspendedsediment concentration, grain size, and turbidity. Data were used to estimate mean daily and annual seasonal suspendedsediment discharge, which were published in U.S. Geological Survey Annual Water-Data Reports. Data were utilized further in this report to develop field-based optical-backscatter calibration equations, which then were used to derive a continuous time series (15-minute interval) of suspended-sediment concentrations. Sensor fouling and aggradation of the channel bed occurred periodically throughout the project period, resulting in data loss. Although periods of data loss occurred, collection of optical sensor data improved our understanding of suspended-sediment dynamics in the Lagunitas Creek and Walker Creek watersheds by providing continuous time-series storm event data that were analyzed to determine durations of elevated sediment concentrations (periods of time when suspended-sediment concentration was greater than $100 \mathrm{mg} / \mathrm{L}$ ).

Data derived from this project contributed baseline suspended-sediment transport information that will be used to develop and implement sediment total maximum daily loads for Tomales Bay and its tributary watersheds, and provides supporting information for additional total maximum daily loads (pathogens, nutrients, and mercury) and restoration efforts for four federally listed aquatic species that are affected directly by sediment loading in the Tomales Bay watershed. In addition, this project provided an opportunity to evaluate the suitability of using optical data as a surrogate for more traditional labor-intensive methods of measuring suspendedsediment transport in steep coastal watersheds.

\section{Introduction}

The Federal Clean Water Act requires states to identify impaired water bodies and to define total maximum daily loads (TMDLs) that a water body can receive and still meet water-quality criteria and attain beneficial uses. Tomales Bay and its two primary tributary watersheds, Lagunitas Creek and Walker Creek, are listed as "impaired by sediment" by the San Francisco Bay Regional Water Quality Control Board (SFRWQCB). Sediment TMDLs are scheduled for

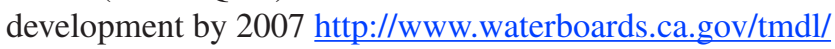
docs/303dlists2006/final/r2 final303dlist.pdf. Data derived from this project provide baseline information that will be used to develop and implement sediment TMDLs for Tomales Bay and its watersheds, and to provide supporting information for additional TMDLs (pathogens, nutrient, and mercury) and restoration efforts for four federally listed aquatic species that are affected directly by sediment loading in the Tomales Bay watershed. The federally listed species include coho salmon, steelhead trout, California freshwater shrimp, and California red-legged frogs.

Data collection included daily and seasonal (October to May) suspended-sediment monitoring and more frequent (15-minute) optical-backscatter (turbidity) monitoring at two U.S. Geological Survey (USGS) streamflow-gaging stations: Lagunitas Creek at Samuel P. Taylor State Park, California (Lagunitas Creek SPT) and Walker Creek near Marshall, California, (Walker Creek). Available funding was limited for data collection at the Lagunitas Creek near Point Reyes gaging station (Lagunitas Creek PRS). Data collection at this site included periodic seasonal suspended-sediment sampling, and more frequent (15-minute) optical-backscatter monitoring. Lack of sufficient sediment sampling ( $\mathrm{n}=14$ over the 3 -year project period) at Lagunitas Creek PRS resulted in insufficient data to develop a reasonable field-based calibration equation; thus, only the uncalibrated raw sensor-output voltages are available for this station. Locations of the stream-discharge gaging stations are shown on figure 1. 


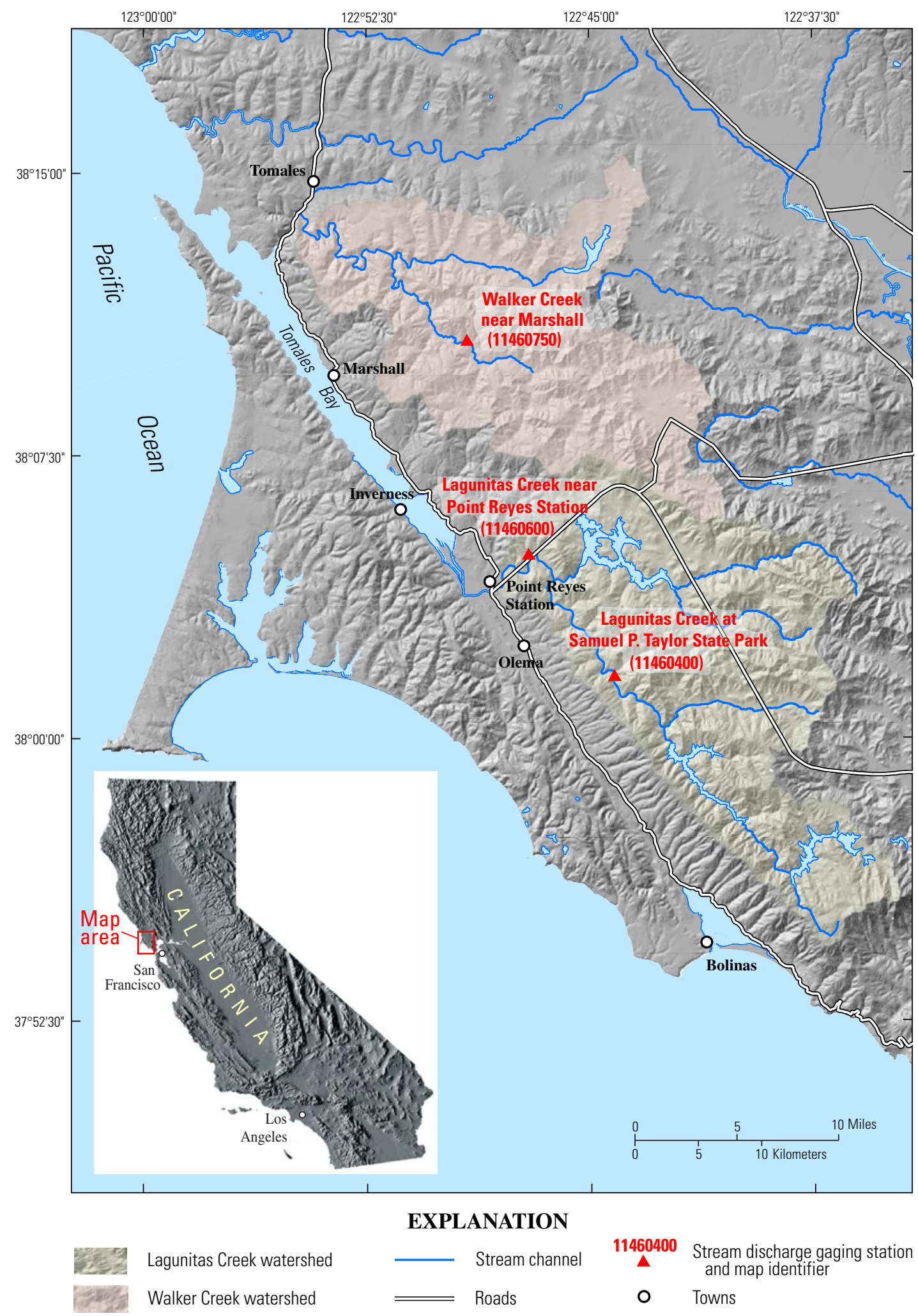

Figure 1. Location of Tomales Bay, Lagunitas Creek watershed, Walker Creek watershed, and sediment and streamflow gaging stations. 
Although sediment discharge in Lagunitas Creek and Walker Creek can vary significantly due to changes in concentration and streamflow, collection and calibration of opticalbackscatter data provided a continuous time-series of concentrations under changing streamflow- and sediment-supply conditions. These continuous time-series sediment data are valuable to the TMDL process and habitat restoration efforts because they capture temporal variability and provide detailed information about the timing of sediment peaks and duration of elevated sediment concentrations.

\section{Purpose and Scope}

This report summarizes suspended-sediment and optical-backscatter data collected by the USGS at three gaging stations in Lagunitas Creek and Walker Creek during water years 2004-06. These data were used to determine mean daily, annual, and event-based suspended-sediment transport within the two primary tributaries to Tomales Bay. Traditional suspended-sediment sampling was supplemented with more frequent (15-minute) optical-backscatter monitoring at all three gages to capture the rapid temporal variations in sediment concentration and to test the use of optical backscatter as a sediment surrogate in this environment.

Daily mean and total seasonal suspended-sediment discharge for stations Lagunitas Creek SPT and Walker Creek are published in the USGS Annual Water-Data Reports (Webster and others, 2005; U.S. Geological Survey, 2006; 2007). This report describes data-collection methods and summarizes suspended-sediment concentration, grain size, turbidity, and optical-backscatter data. Optical-backscatter calibration curves, plots of edited and calibrated optical-backscatter data, and a table of storm-event data also are presented.

\section{Study Area}

Lagunitas Creek and Walker Creek are the two primary tributary watersheds to Tomales Bay. Land use in the 103- $\mathrm{mi}^{2}$ Lagunitas Creek watershed is mixed, with about half of the watershed used for public purposes such as water supply and for a State Park and the other half used for limited agriculture, grazing, and rural residential development. Land use in the 76- $\mathrm{mi}^{2}$ Walker Creek watershed consists primarily of privately owned beef and dairy operations.

Pervasive cutbank and hillslope erosion throughout the study area delivers sediment to mainstem channels, resulting in aggradation of lower tributary channels. Analyses of digitized bathymetric maps from 1861, 1931, 1957, and 1994 indicate that the highest sedimentation rates in Tomales Bay occurred from 1931 to 1957 (Rooney and Smith, 1999).
Haible (1980) documented chronic erosion (channel incision) of 3-15 ft in the upper reaches of Walker Creek and sedimentation (aggradation) of 3-6 ft in the lower reaches of Walker Creek over the period 1915-75. Comparison of topographic maps published between 1862 and 1976 indicates that accumulation of sediment at the Lagunitas delta was greatest from 1861 to 1931 (Neimi and Hall, 1996). Although rates have slowed, erosion and sedimentation in both watersheds continues, Anima and others (1988) reports the accumulation of 10 million $\mathrm{ft}^{3}$ of sediment [roughly more than 37,000 dump truck loads (at $10 \mathrm{yd}^{3}$ each)] on the Lagunitas and Walker deltas after the 1981-82 flood.

\section{Acknowledgments}

This project was funded by the joint National Park Service-USGS Water Quality Assessment and Monitoring partnership program and was developed through coordination with Point Reyes National Seashore. Brannon Ketcham (Point Reyes National Seashore) and Scott Wright (USGS-Sacramento, California) were responsible for project development. Neil Ganju (USGS-Sacramento, California) provided insightful advice throughout the project. Reviews by Scott Wright and Mark Uhrich (USGS-Portland, Oregon) improved the original manuscript.

\section{Methods of Data Collection and Analysis}

Streamflow, optical-backscatter, and suspended-sediment data were collected and analyzed using USGS methods for streamflow (Rantz and others, 1982), in situ water-quality monitors (Wagner and others, 2006), and fluvial sediment (Edwards and Glysson, 1999). Daily mean streamflow and suspended-sediment discharge data, as well as annual minimum and maximum streamflow for the study period, are published separately in USGS Annual Water-Data Reports (Webster and others, 2005; U.S. Geological Survey, 2006; 2007). The published streamflow and suspended-sediment data also are available at http://waterdata.usgs.gov/nwis/. Streamflow, gage heights, edited optical-backscatter data, and estimated suspended-sediment concentrations (calculated from calibrated optical-backscatter data) are presented at 15-minute intervals in Appendix A (see at AppendA.xls). Suspended-sediment concentrations, grain-size, and turbidity data for individual samples are presented in Appendix B (see at AppendB.xls). 


\section{Sampling and Analysis of Suspended-Sediment Samples}

Depth-integrated, single-vertical, and multi-vertical suspended-sediment samples were collected during water years 2004-06 following standard USGS procedures (Edwards and Glysson, 1999). Samples at two gaging stations (Lagunitas Creek SPT and Walker Creek) were collected 2-7 days per week, depending on hydrologic conditions, with increased frequency of sampling during periods of higher streamflow. A total of 14 periodic samples were collected throughout the 3 -year project period at Lagunitas Creek PRS. Typically, two sequential suspended-sediment concentration (SSC) samples were collected during each visit, and additional samples were collected periodically throughout the water year for grain-size and turbidity analysis. Concentrations (SSC), grain size, and turbidity were measured at the USGS sediment laboratory in Marina, California, using methods described by Guy (1969) and Anderson (2005).

\section{Optical Sensor Description and Operation}

Optical backscatter has been used successfully as a surrogate for suspended-sediment concentration in low-gradient rivers such as the Lower Sacramento River (Schoellhamer and Wright, 2003) and steep mountain rivers such as the Yuba River (Curtis and others, 2006). Developed and tested by Downing and others (1981), optical backscatter sensors (OBS) emit infrared light into the water column, which is reflected on contact with suspended particles. A series of photodiodes positioned around the emitter detects the light reflectance (backscatter), and an empirical calibration is used to convert sensor output voltage into suspended-sediment concentration. One can think of the calibration as the relation between the mass of sediment per unit volume of water (suspended-sediment concentration) and the number of particles per unit volume of water (backscatter).

Backscatter is related inversely to particle size such that the sensitivity of the OBS changes with particle size by more than an order of magnitude; therefore, large changes in the particle size distribution of suspended material can be problematic when developing calibrations. For example, during a storm event, increasing streamflow results in the suspension of larger sized particles. As progressively more sand travels in suspension, the mass of sediment (per unit volume of water in suspension) increases at a different rate than the number of particles (per unit volume of water), resulting in a nonlinear calibration relation. Also, there is an upper limit to the concentrations that optical sensors can measure that may be exceeded in smaller, steeper creeks with flashier hydrographs. This complication can be addressed by decreasing the sensitivity of the OBS, which is accomplished by adjusting the sensor gain, whereby the highest output voltage $(2,500 \mathrm{mV})$ corresponds to the maximum expected sediment concentration.

Continuously recording optical backscatter sensors (OBS-3) were installed at three gaging stations [Lagunitas Creek at Samuel P. Taylor (SPT) State Park, Lagunitas Creek at Point Reyes Station (PRS), and Walker Creek]. Data loggers stored output in millivolts from the optical sensors at 15-minute intervals and recorded data were telemetered from the sites or downloaded during site visits. Raw sensor output data (in millivolts) were archived in the USGS automated data-processing system (ADAPS) and retrieved and edited to remove invalid data. The criteria for identifying and removing invalid data included: (1) small groups (one to three) of anomalously high data points (assumed to represent debris or fish passage); (2) anomalous periods of moderate-to-high sensor output with no associated changes in the streamflow record or concentrations of sediment samples measured in the laboratory (assumed to represent bed aggradation); (3) progressive increases in sensor output prior to sensor cleaning followed by drastic reductions after cleaning (assumed to represent fouling); and (4) data that exceeded the upper limit of concentrations that the optical sensors were capable of measuring.

Sediment samples and optical data were collected seasonally (October to May), and measurement errors were assessed periodically throughout the water year. Measurement errors can lead to data loss and may occur due to instrumentation or environmental effects including: electronic sensor drift, fouling, and changes to the morphology of the channel bed. Sensors were field checked for electronic drift at the beginning and end of each water year using a 4,000-nephelometric turbidity unit (NTU) formazin standard, which was diluted using deionized water into a series of calibration solutions ranging from 40 to 1,200 NTU. Sensors were cleaned and immersed in the calibration solution and the voltage output was recorded. Sensor drift ranged from 1 to 4 percent, which fell within the recommended 5 percent calibration criteria (Wagner and others, 2006). Sensor fouling and aggradation of the channel bed occurred periodically throughout the project period, resulting in data loss. Fouling, due to biological or chemical particles accumulating on the sensors, occurred at all three sites and was of concern primarily during low-flow periods. Aggradation of the channel bed was problematic at Lagunitas Creek SPT and Walker Creek, resulting in extended periods of invalid data. Data loss was minimized by cleaning the sensor one to two times per week, as flow conditions allowed, and by periodically adjusting the distance of the sensors above the channel bed. 


\section{Optical Sensor Calibration}

Calibration of sensor output voltage to suspended-sediment concentration can vary significantly with particle size and color (Conner and de Visser, 1992; Levesque and Schoelhammer, 1995; Sutherland and others, 2000). In lieu of using a laboratory-based calibration, the optical sensors were calibrated using field data on a site-specific basis. Therefore, the raw data, which represents sensor output voltages, is reported in millivolts $(\mathrm{mV})$, as opposed to turbidity units such as backscatter units (BU) or formazin backscatter units (FBU).

Although the data collected at Lagunitas Creek PRS were not sufficient to develop a reasonable calibration, adequate data were available to develop empirical calibrations for Lagunitas Creek SPT and Walker Creek. OBS at these two sites were calibrated using SSC data from width/depthintegrated, suspended-sediment samples. The SSC and OBS data were nonlinear and displayed nonconstant variance of the residuals (heteroscedasticity). In cases such as this, Hersel and Hirsch (1992) recommend transforming the data (for example, $\left.\log \mathrm{x}, 1 / \mathrm{x}, \mathrm{x}^{1 / 2}\right)$ to achieve constant variance of the residuals (homoscedasticity) required for ordinary least-squares regression. Analysis of the residuals indicated that only a log transformation resulted in a satisfactory decrease in the variance at higher concentrations and sensor output voltages such that homoscedasticity could be achieved.

The SSC and associated OBS data (collected contemporaneously) were transformed to base-10 logarithmic values, and the $\log$ values then were used to calculate a linear leastsquares regression:

$$
\log \mathrm{SSC}=\log a+b \log \mathrm{OBS}
$$

The regression converted to power form is:

$$
\mathrm{SSC}=a \mathrm{OBS}^{b}
$$

\section{Storm Event Analysis}

The first significant runoff event at the beginning of each water year (first flush) and all subsequent storm events (greater than 200 percent of the mean daily flow) were analyzed if valid data were available. Mean daily streamflows at Lagunitas Creek SPT, Lagunitas Creek PRS, and Walker Creek were 44, 93, and $35 \mathrm{ft} / \mathrm{s}$, respectively. Peak streamflow and storm durations were estimated using 15-minute streamflow data (Appendix A). Suspended-sediment yield and periods of time during which suspended-sediment concentrations were greater than $100 \mathrm{mg} / \mathrm{L}$ were estimated using calibrated optical backscatter data (Appendix A).

\section{Results}

\section{Calibration Equations}

Empirical calibrations for optical sensors, developed using regression analysis and used to convert sensor output voltage into SSC, are as follows and also are shown in figures 2 and 3 :

$$
\begin{aligned}
& \text { Lagunitas SPT first sensor }(\mathrm{n}=114) \text { : } \\
& \text { SSC }=-1.229(\mathrm{OBS})^{1.204} \\
& \text { Lagunitas SPT second sensor }(\mathrm{n}=249) \text { : } \\
& \text { SSC }=-2.253(\mathrm{OBS})^{1.507}
\end{aligned}
$$

$$
\begin{gathered}
\text { Walker Creek first sensor }(\mathrm{n}=94): \mathrm{SSC}= \\
-1.287(\mathrm{OBS})^{1.287}
\end{gathered}
$$

Walker Creek second sensor $(\mathrm{n}=429)$ :

$$
\mathrm{SSC}=-2.282(\mathrm{OBS})^{1.60}
$$

Significant scatter in the calibration datasets resulted in moderate-to-poorly fit calibration equations such that the calibrations may not be reliable for actual suspended-sediment predictions.

The total variation in predicted suspended-sediment concentrations using the calibration equations is given by $\mathrm{r}^{2}$. The strength of the regression relation can be measured using the $r^{2}$ values, which vary from 0.583 to 0.863 (figs. 2 and $\underline{3}$ ). There is a lower likelihood for predicting suspended-sediment concentrations closest to the true values using calibration equations with lower $r^{2}$ values. Although the $r^{2}$ values indicate a moderate fit for Walker Creek and the first probe at Lagunitas SPT, the assumed log-linear relation does not hold for the second probe at Lagunitas SPT.

\section{Monitoring Site Data}

Suspended-sediment data collected in the Tomales Bay watershed were used to estimate mean daily and annual seasonal suspended-sediment discharge for Lagunitas Creek SPT and Walker Creek, which were published in USGS Annual Water-Data Reports (Webster and others, 2005; U.S. Geological Survey, 2006; 2007). Annual seasonal suspendedsediment yield at Tomales Bay watershed stream-discharge gaging stations is shown in table 1. Although the drainage area at the Lagunitas Creek SPT and Walker Creek gaging stations are similar, 34.3 and $31.1 \mathrm{mi}^{2}$, respectively, the annual seasonal suspended-sediment yield at Walker Creek is greater. Throughout the 3-year project period, Walker Creek transported 61-68 percent of the combined measured suspendedsediment discharge at the two gaging stations. 

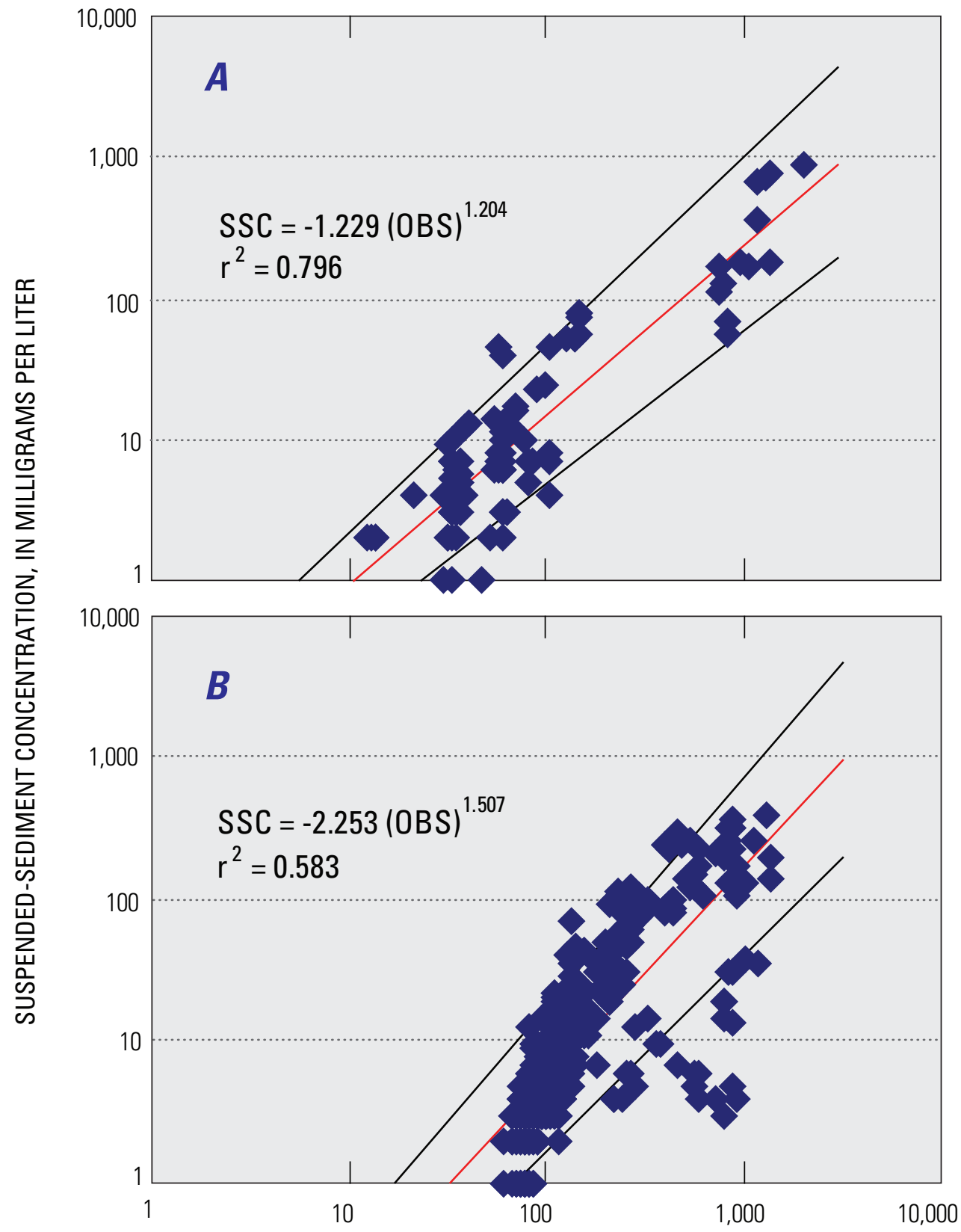

OPTICAL BACKSCATTER SENSOR OUTPUT, IN MILLIVOLTS

\section{EXPLANATION}

Regression line

Sample datapoints

— 95 percent prediction interval

Figure 2. Optical-backscatter sensor calibration, $(A)$ first sensor deployed November 21, 2003, through January 21, 2005, and (B) second sensor deployed January 21, 2005, through June 1, 2006, at Lagunitas Creek at Samuel P. Taylor State Park, California. 

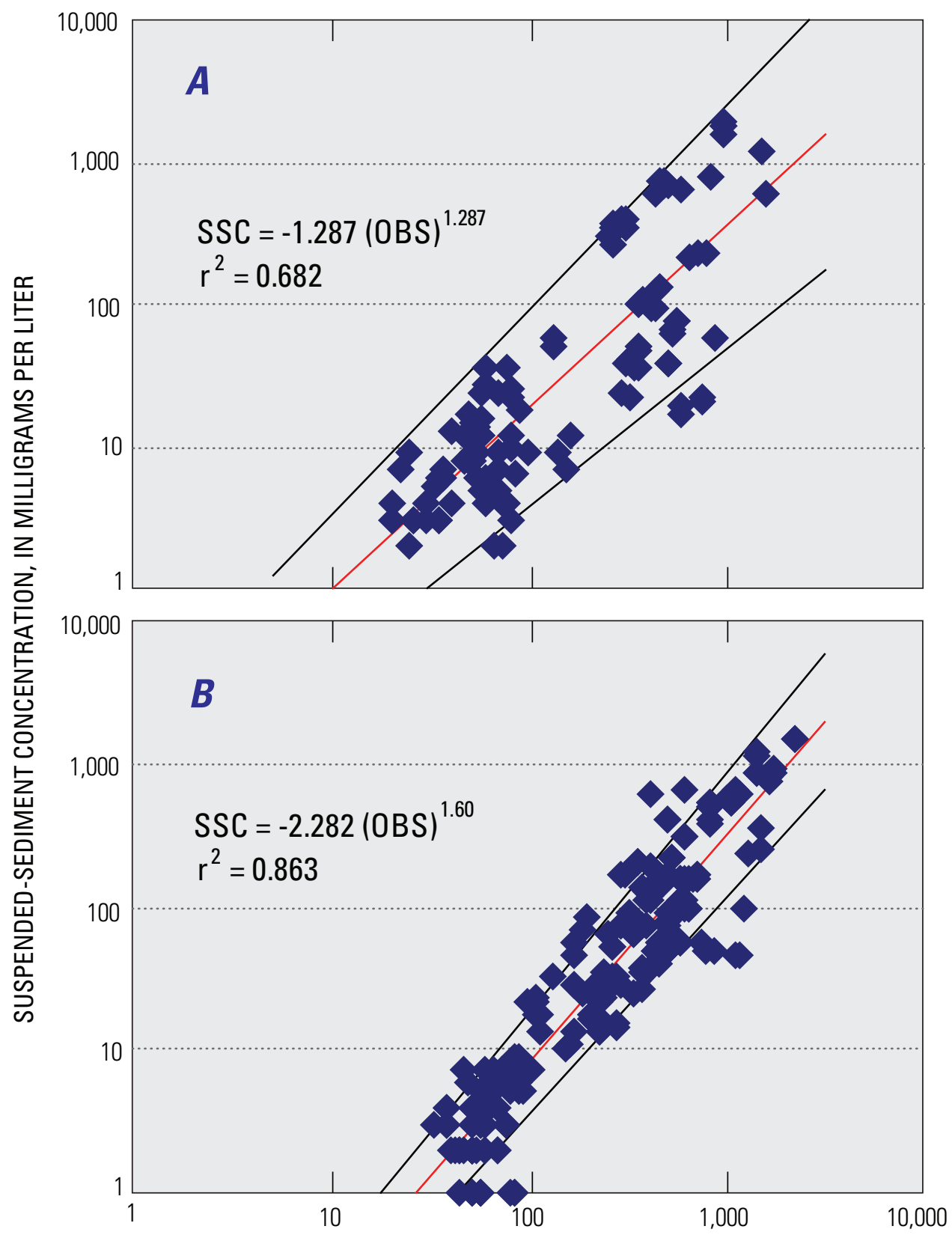

OPTICAL BACKSCATTER SENSOR OUTPUT, IN MILLIVOLTS

\section{EXPLANATION}

Regression line

Sample datapoints

\section{5 percent prediction interval}

Figure 3. Optical-backscatter sensor calibration, $(A)$ first sensor deployed November 21, 2003, through January 21, 2005, and (B) second sensor deployed January 21, 2005, through June 1, 2006, at Walker Creek near Marshall, California. 
Table 1. Annual seasonal suspended-sediment yield at Tomales Bay watershed stream gaging stations during water years 2004, 2005, and 2006.

[See figure 1 for station locations. $\mathrm{mi}^{2}$, square mile; tons $/ \mathrm{mi}^{2}$, ton per square mile]

\begin{tabular}{|c|c|c|c|}
\hline \multirow[b]{2}{*}{ Gaging Station } & \multicolumn{3}{|c|}{ Water Year } \\
\hline & $\begin{array}{c}2004 \\
\text { (tons/mi²) }\end{array}$ & $\begin{array}{c}2005 \\
\text { (tons/mi²) }\end{array}$ & $\begin{array}{c}2006 \\
\text { (tons/mi²) }\end{array}$ \\
\hline $\begin{array}{l}\text { Lagunitas Creek SPT } \\
\qquad\left(34.3 \mathrm{mi}^{2}\right)\end{array}$ & 140 & 64 & 1,080 \\
\hline Walker Creek (31.1 $\left.\mathrm{mi}^{2}\right)$ & 223 & 125 & 2,300 \\
\hline
\end{tabular}

The maximum number of OBS data points collected per year, when collected seasonally from October 1 to May 31, is 23,424 data points (96 data points per day for 244 days). The actual number of usable data points in this study was considerably less due to invalid data. The usable percentage of valid optical backscatter data collected at Tomales Bay watershed stream gaging stations ranged from 20 to 87 percent during the 3-year project period (table 2). Interruptions in the OBS data record at all three gaging stations were caused by OBS measurements that exceeded the upper measurement limit, malfunctioning of the sensor and (or) recording equipment, aggradation and scour of the channel bed, and fouling of the sensor. The upper limit of measurable concentrations was violated periodically at all three gaging stations throughout the 3-year project period primarily during peak runoff events. At Lagunitas SPT, the sensor and (or) the data recorder malfunctioned during water year 2005, resulting in data loss from October 1, 2004, through January 21, 2005. Replacement sensors capable of measuring higher concentrations (the sensor gain was turned up) at Lagunitas Creek SPT and Walker Creek were deployed on January 21, 2005. Aggradation of the channel bed periodically buried the sensors at Lagunitas Creek SPT during water years 2004 and 2005 and at Walker Creek during water year 2005, resulting in anomalously high sensor output for associated low measured SSC values. This especially is evident in the calibration data for the second sensor at Lagunitas Creek SPT (fig. 2).

Table 2. Percentages of valid optical backscatter data collected at Tomales Bay watershed stream gaging stations during water years 2004, 2005, and 2006.

[See figure 1 for station locations]

\begin{tabular}{lccc}
\hline \multicolumn{1}{c}{ Gaging Station } & \multicolumn{3}{c}{ Water Year } \\
\cline { 2 - 4 } & $\mathbf{2 0 0 4}$ & $\mathbf{2 0 0 5}$ & $\mathbf{2 0 0 6}$ \\
\hline Lagunitas Creek SPT & $38 \%$ & $38 \%$ & $87 \%$ \\
Lagunitas Creek PRS & $60 \%$ & $81 \%$ & $81 \%$ \\
Walker Creek & $20 \%$ & $79 \%$ & $65 \%$ \\
\hline
\end{tabular}

${ }^{1}$ Table footnote
Invalid data were identified and deleted resulting in edited datasets for each gaging station. Streamflow, estimated SSC time-series data, and measured SSC data from samples collected at Lagunitas SPT during water years 2004-06 are presented in figure 4A-C. Streamflow and edited (invalid data removed) but uncalibrated sensor output data collected at Lagunitas PRS during WY 2004-06 are presented in figure 5A-C. Streamflow, estimated SSC time-series data, and measured SSC data from samples collected at Walker Creek during water years 2004-06 are presented in figure 6A-C.

Grain size analysis of suspended-sediment samples collected at Lagunitas Creek SPT and Walker Creek (Appendix B) shows that fine-grained sediment (percent less than 0.063 $\mathrm{mm}$ ) dominates the suspended load. Fine-grained sediment represented approximately 70 percent of the suspended material collected at Lagunitas Creek SPT and Walker Creek; whereas, only 22 percent of the samples collected at Lagunitas Creek SPT and 28 percent of the samples collected at Walker Creek contained sand-sized particles.

Calibration of the optical-backscatter data requires a relatively stable particle-size distribution. This condition generally was met at Lagunitas Creek SPT, but not at Walker Creek, and may have contributed to scatter in the calibration datasets, thereby resulting in moderate-to-poorly fit calibration equations. Plots of the ratio of suspended-sediment concentration to sensor output voltage, as a function of suspended particles finer than $0.063 \mathrm{~mm}$ (figs. 7 and $\underline{8}$ ) show that at higher concentrations Walker Creek has greater percentages of sand in suspension.

\section{Storm Events}

The OBS continuous time-series data captured the rapid temporal variations in sediment concentration during storms throughout water years 2004-06. Peak streamflow, storm duration, estimated suspended-sediment yield, and duration of elevated suspended-sediment concentrations for individual storm events are presented in table 3. Although regression analyses indicate that OBS calibrations may not be reliable for actual suspended-sediment predictions, the OBS storm data provide a means with which to characterize the relative magnitude and duration of storms that may result in deleterious effects on atrisk aquatic species in the Tomales Bay watershed. 


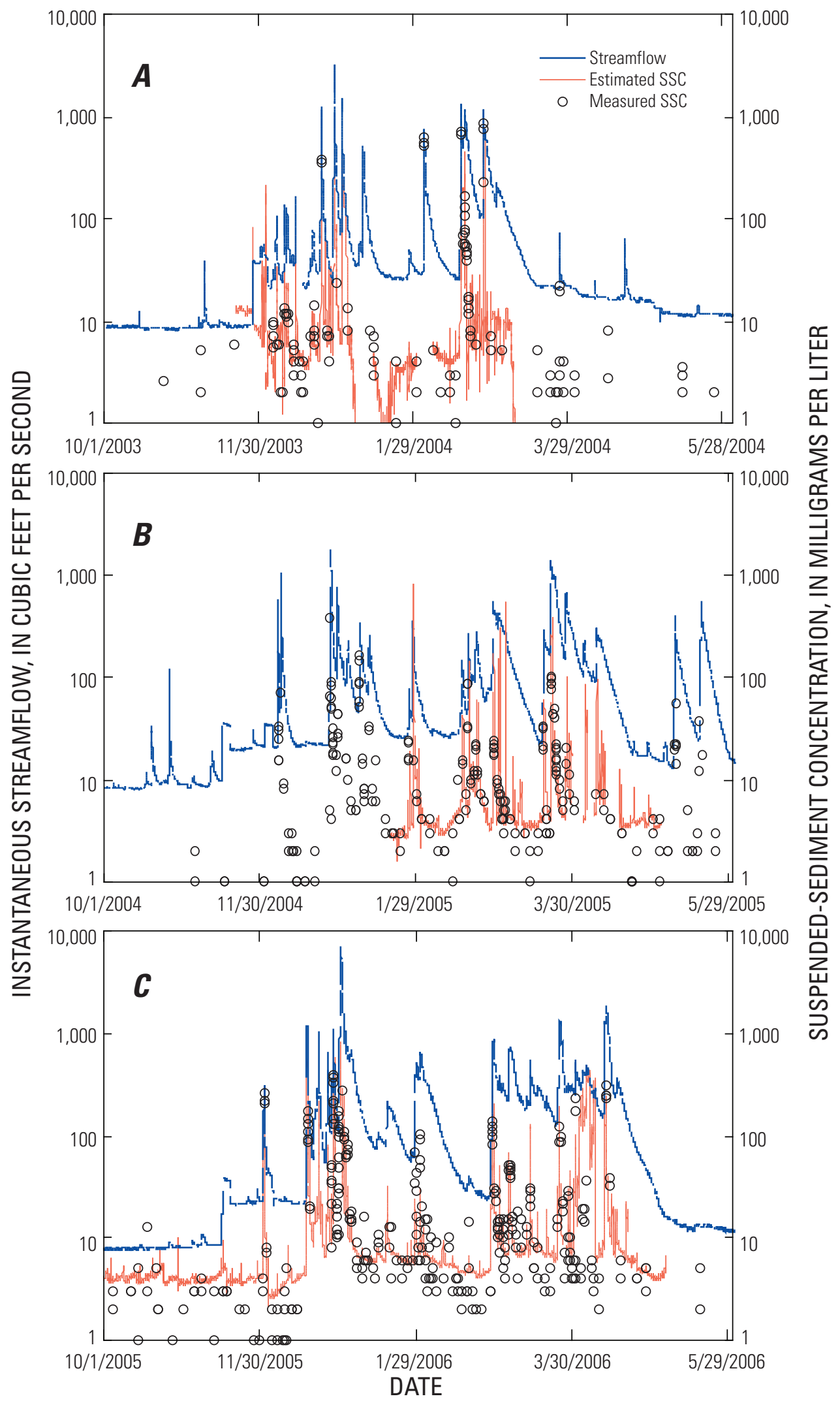

Figure 4. Instantaneous streamflow, measured suspended-sediment concentrations, and estimated suspended-sediment concentrations, Lagunitas Creek at Samuel P. Taylor State Park, California, $(A)$ water year 2004, $(B)$ water year 2005, and (C) water year 2006. 


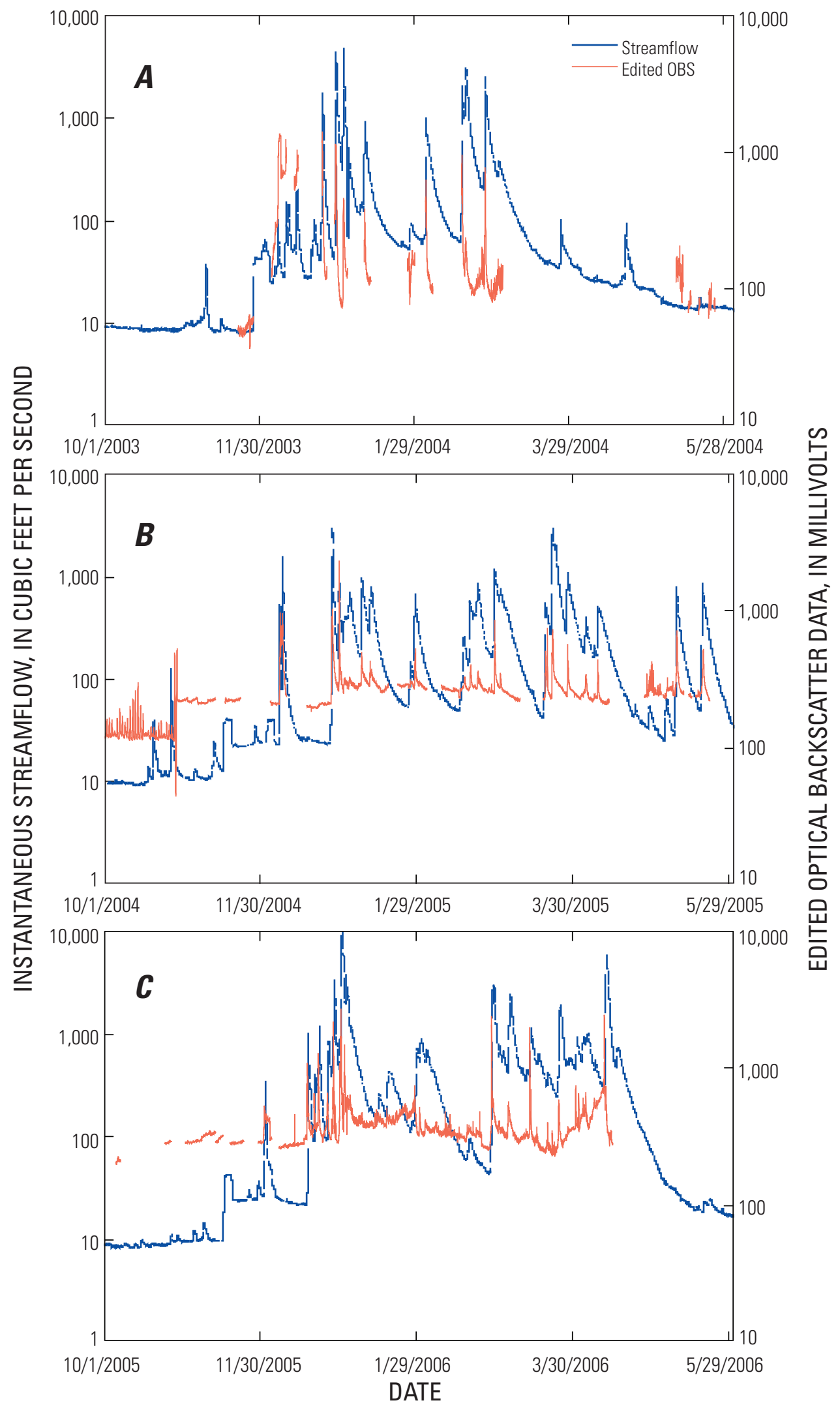

Figure 5. Instantaneous streamflow and uncalibrated/edited optical-backscatter data, Lagunitas Creek near Point Reyes Station, California, $(A)$ water year 2004, $(B)$ water year 2005, and $(C)$ water year 2006. 


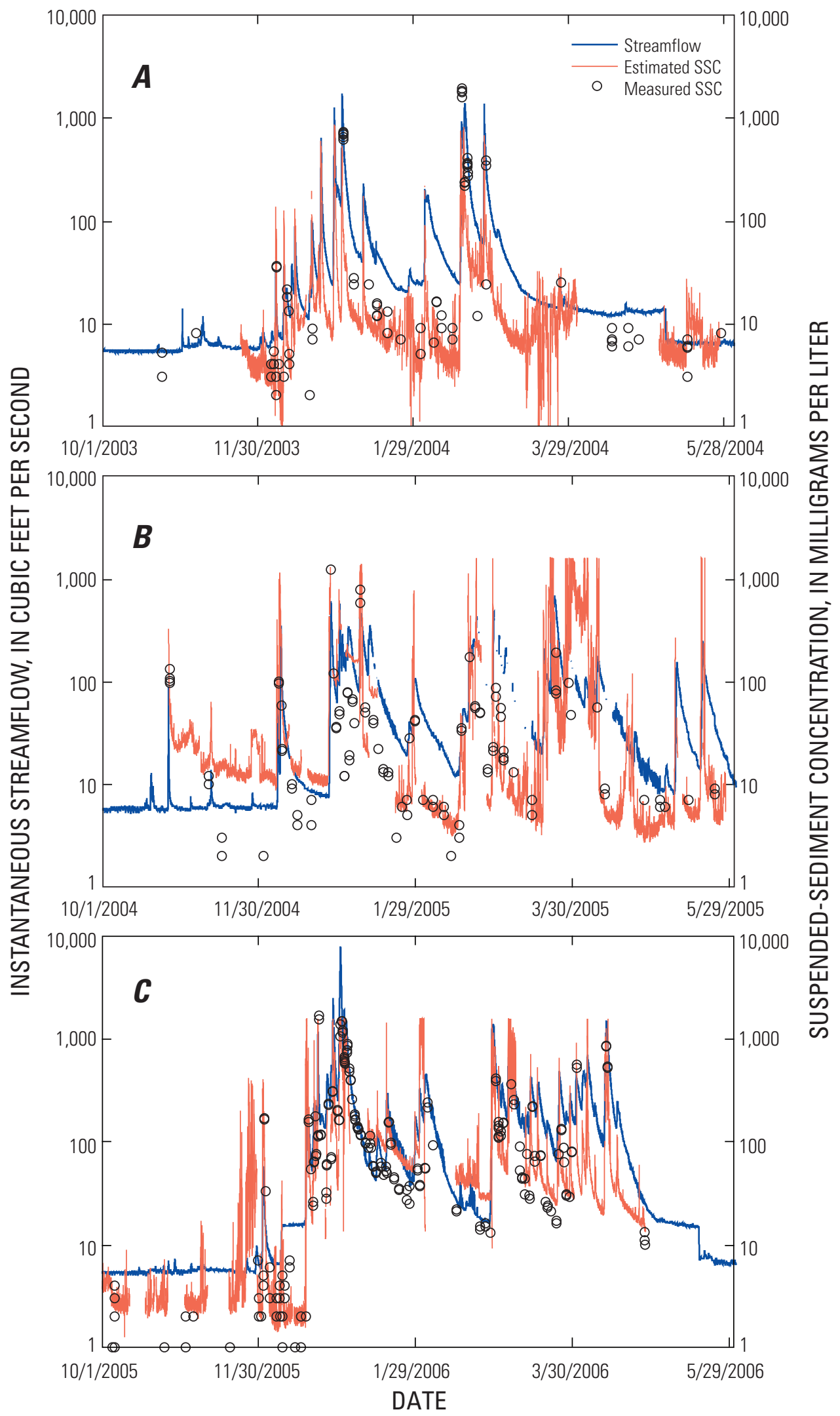

Figure 6. Instantaneous streamflow, measured suspended-sediment concentrations, and estimated suspended-sediment concentrations, Walker Creek near Marshall, California, $(A)$ water year 2004, $(B)$ water year 2005, and $(C)$ water year 2006. 

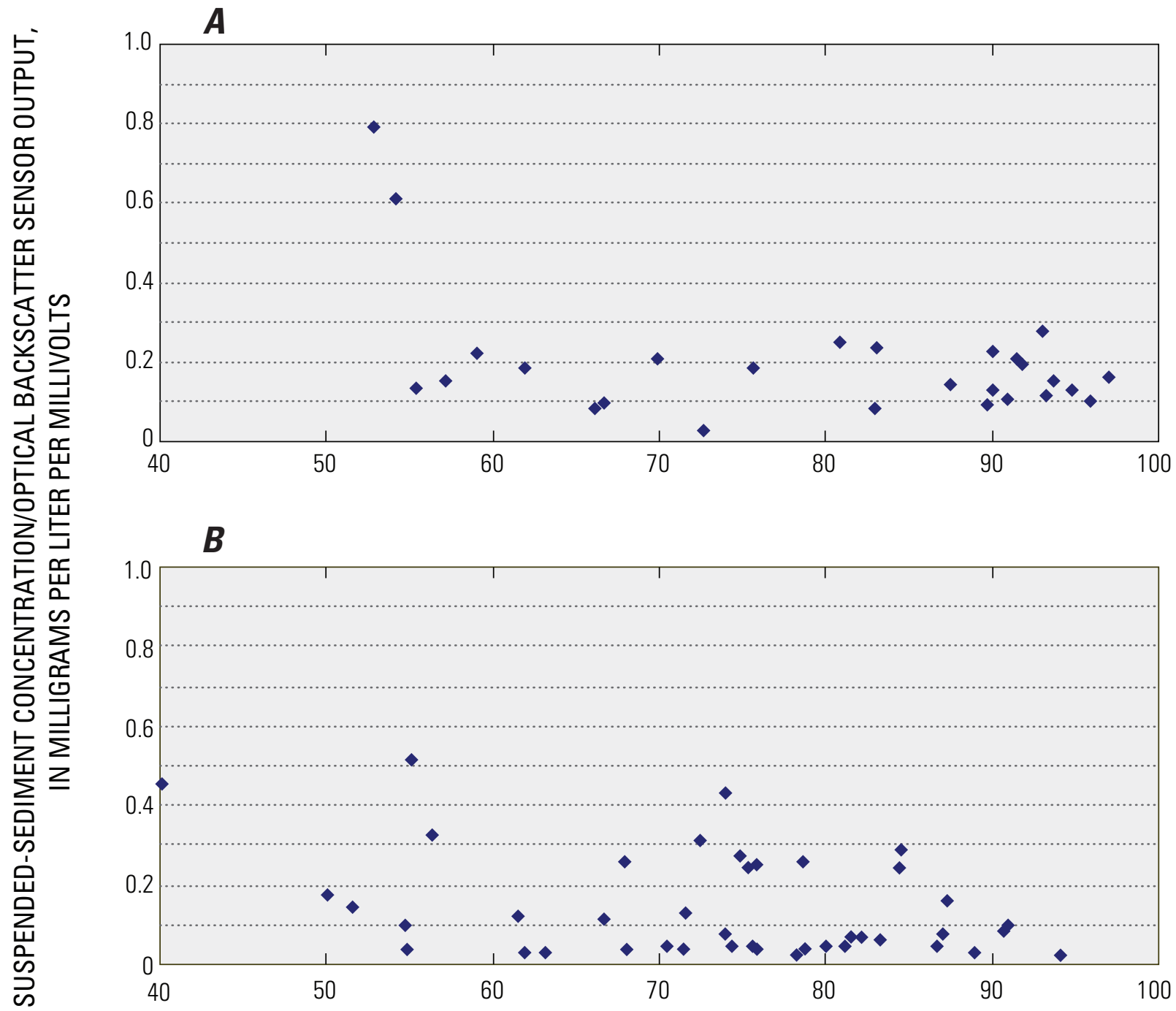

PERCENTAGE OF SUSPENDED-SEDIMENT PARTICLES FINER THAN 0.063 MILLIMETER

Figure 7. Ratio of suspended-sediment concentration to optical-backscatter sensor-output voltage as a function of suspended particles finer than 0.063 millimeter, $(A)$ first sensor deployed November 21, 2003, through January 21, 2005, and $(B)$ second sensor deployed January 21, 2005, through June 1, 2006, at Lagunitas Creek at Samuel P. Taylor State Park, California. 

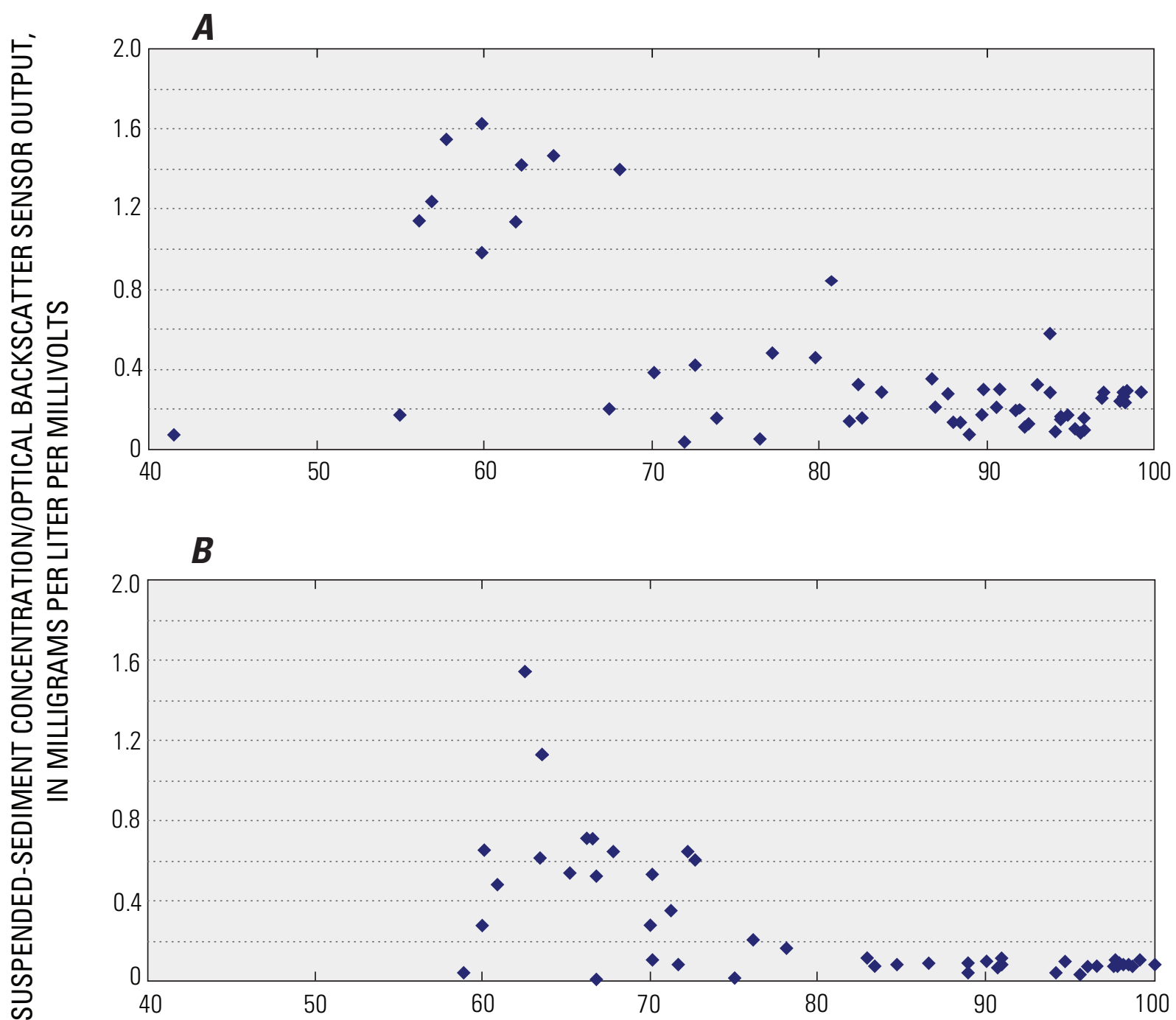

PERCENTAGE OF SUSPENDED-SEDIMENT PARTICLES FINER THAN 0.063 MILLIMETER

Figure 8. Ratio of suspended-sediment concentration to optical-backscatter sensor-output voltage as a function of suspended particles finer than 0.063 millimeter, $(A)$ first sensor deployed November 21, 2003, through January 21, 2005, and $(B)$ second sensor deployed January 21, 2005, through June 1, 2006, at Walker Creek near Marshall, California. 
Table 3. Storm event data for Tomales Bay watershed gaging stations during water years 2004, 2005, and 2006.

[See figure 1 for station locations. $\mathrm{ft}^{3} / \mathrm{s}$, cubic foot per second; $\mathrm{mi}^{2}$, square mile; tons $/ \mathrm{mi}^{2}$; ton per square mile; —, no data; >, greater than]

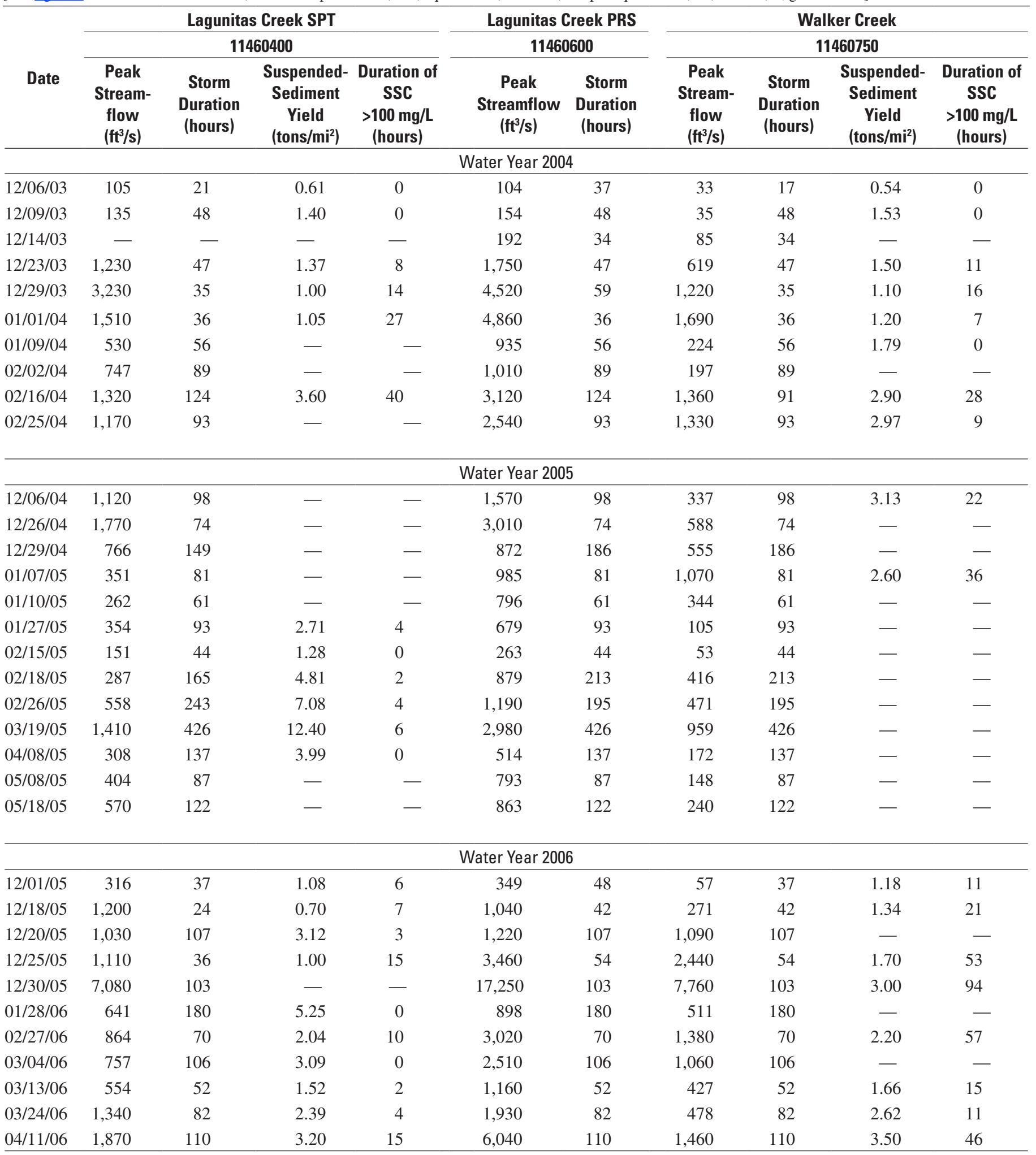




\section{Summary}

Suspended-sediment transport in the Tomales Bay watershed during water years 2004-06 is characterized in this report. The U.S. Geological Survey collected suspended-sediment concentration, grain size, turbidity, and optical backscatter data at three gaging stations: Lagunitas Creek Samuel P. Taylor (SPT) (station 11460400), Lagunitas Creek Point Reyes Station (PRS) (station 11460600), and Walker Creek (station 11460750). Sediment samples analyzed for concentrations and grain size were used to calibrate optical sensor output to suspended-sediment concentrations at Lagunitas Creek SPT and Walker Creek. Insufficient sediment data were collected at Lagunitas Creek PRS to develop a calibration equation. These data will be valuable during the development and implementation of total maximum daily loads (TMDLs) for the Tomales Bay watershed, which is scheduled for completion in 2007, and for restoration efforts for four federally listed aquatic species that are affected directly by sediment loading in the Tomales Bay watershed. This project also provided an opportunity to evaluate the suitability of optical sensors in steep coastal watersheds, and a chance to compare optical sensors with daily sediment stations.

Significant optical-data loss occurred due to measurements that exceeded the sensor's upper measurement limit, malfunctioning of the sensor and (or) recording equipment, aggradation of the channel bed, and fouling of the sensors. Percent valid data ranged from 20 to 87 percent during the 3 -year project period (water years 2004-06). Although periods of data loss occurred, collection of optical-sensor data improved our understanding of suspended-sediment dynamics in the Lagunitas Creek and Walker Creek watersheds by providing continuous time-series storm event data that were analyzed to determine durations of elevated sediment concentrations (periods of time where SSC was greater than 100 $\mathrm{mg} / \mathrm{L})$.

Data collection is challenging in dynamic systems with high sediment yields, unstable channel bed conditions, and wide variations in the concentration and particle size of the suspended load. Poorly fit calibration equations decreased the reliability of using optical data to determine actual sediment discharge in this study. Improving the reliability of optical sensors as surrogates for more traditional labor-intensive methods of measuring suspended-sediment transport would require relocation of the optical sensors to more stable stream reaches to avoid changing channel bed elevations. Use of multiple optical sensors at a single site, with the gain of two sensors adjusted to measure average conditions (lower sensor gain) and peak conditions (higher sensor gain), also may significantly improve data collection. Limited funding was available for sediment data collection at Lagunitas Creek PRS, which has a relatively stable channel bed and deep gaging pool. The Lagunitas Creek PRS site shows the greatest potential for using an optical backscatter sensor (OBS) as a surrogate for more traditional sampling. Interruptions in the data record at Lagunitas Creek PRS primarily were due to biofouling; therefore, data loss could be improved easily at this site by regular cleaning and maintenance of the OBS.

\section{References Cited}

Anderson, C.W., September 2005, Turbidity (version 2.1): U.S. Geological Survey Techniques of Water-Resources Investigations, book 9, chap. A6, section 6.7, accessed September 24, 2004 from http://pubs.water.usgs.gov/twri9A6

Anima, Roberto, Bick, J.L., and Clifton, H.E, 1988, Sedimentologic consequences of the storm in Tomales Bay, section 16 in Ellen, S.D. and Wieczorek, G.F., eds., Landslides, floods, and marine effects of the storm of January 3-5, 1982, in the San Francisco Bay region, California: U.S. Geological Survey Professional Paper 1434, 17 p. 7.

Conner, C.S. and De Visser, A.M., 1992, A laboratory investigation of particle size effects on an optical backscatterance sensor: Marine Geology, v. 108, no. 2, p. 151-159.

Curtis, J.A., Flint, L.E., Alpers, C.N., Wright, S.A., and Snyder, N.P., 2006, Use of sediment rating curves and optical backscatter data to characterize sediment transport in the Upper Yuba River watershed, California, 2001-03: U.S. Geological Survey Scientific Investigations Report 20055246, 74 p.

Downing, J.P., Sternberg, R.W., and Lister, C.R.B, 1981, New instrumentation for the investigation of sediment suspension processes in the shallow marine environment: Marine Geology, v. 42, p. 19-34.

Edwards, T.K. and Glysson, G.D., 1999, Field methods for measurement of fluvial sediment: U.S. Geological Survey Techniques of Water-Resources Investigations, book 3, chap. C2, 89 p.

Guy, H.P., 1969, Laboratory theory and methods for sediment analysis: U.S. Geological Survey Techniques of WaterResources Investigations, book 5, chap. C1, 58 p.

Haible, William, 1980, Holocene profile changes along a California coastal stream: Earth Surface Processes, v. 5, 249-264.

Helsel D.R. and Hirsh R.M., 1992, Statistical methods in water resources: New York, Elsevier, 522 p.

Levesque, V.A. and Schoellhamer, D.H., 1995, Summary of sediment resuspension monitoring activities, Old Tampa Bay and Hillsborough Bay, Florida, 1988-91: U.S. Geological Survey Water-Resources Investigations Report 94-4081, $31 \mathrm{p}$. 
Neimi, T.M. and Hall, N.T., 1996, Historical changes in the tidal marsh of Tomales Bay and Olema Creek, Marin County, California: Journal of Coastal Research, v. 12, no. 1, p. 90-102.

Rantz, S.E. and others, 1982, Measurement and computation of streamflow: U.S. Geological Survey, Water-Supply Paper $2175,631 \mathrm{p}$.

Rooney, J.J. and Smith, S.V., 1999, Watershed landuse and Bay sedimentation: Journal of Coastal Research, v. 15, no. 2 , p. $478-485$

Schoellhamer, D.H. and Wright, S.A., 2003, Continuous measurement of suspended-sediment discharge in rivers by use of optical backscatterance sensors: International Association of Hydrological Sciences (IAHS) Publication 283, p. 28-36.

Sutherland, T.F., Lane, P.M., Amos, C.L., and Downing, J., 2000, The calibration of optical backscatter sensors for suspended sediment of varying darkness levels: Marine Geology, v. 162, p. 587-597.
U.S. Geological Survey, 2006, Water resources data, California, water year 2005:Water-Data Report CA-05 (http:// web10capp.er.usgs.gov/adr lookup/wdr-ca-05/)

U.S. Geological Survey, 2007, Water-resources data for the United States, Water Year 2006: U.S. Geological Survey Water-Data Report WDR-US-2006, accessed April 1, 2007, at http://pubs.water.usgs.gov/wdr2006

Wagner, R.J., Boulger, R.W., Jr., Oblinger, C.J., and Smith, B.A., 2006, Guidelines and standard procedures for continuous water-quality monitors-Station operation, record computation, and data reporting: U.S. Geological Survey Techniques and Methods 1-D3, 51 p. + 8 attachments; accessed April 10, 2006, at http://pubs.water.usgs.gov/tm1d3

Webster, M.D., Pope, G.L., Friebel, M.F., Freeman, L.A., and Brockner, S.J., 2005, Water resources data-California, water year 2004. volume 2. Pacific Slope basins from Arroyo Grande to Oregon state line except Central Valley: Water-Data Report CA-04-2, 472 p. 